\title{
Changing the Newsroom Culture: A FoUR-YEAR CASE STUDY of Organizational DeVelopment at THE St. Louis Post-Dispatch
}

By Peter J. Gade and Earnest L. Perry

This longitudinal case study of change at the St. Louis PostDispatch measured newsroom employee perceptions of organizational development, newsroom restructuring (from beats to teams), and public journalism during Cole C. Campbell's tenure as editor, 19962000. Results indicate initial optimism about change faded within a year. Over the course of the study, respondents failed to see a connection between change initiatives and producing a better newspaper. Journalists did not experience empowerment associated with teambased systems.

The idea that "change" is a constant in life has been understood by Western philosophers for more than 2,500 years. In a journalistic sense, accepting change as an element of life suggests journalism never is a specific set of practices and values; it is constantly becoming something that it currently is not. ${ }^{1}$ This evolutionary process became increasingly clear for U.S. newspapers in the past decade, as the industry has faced both internal and external challenges on nearly every front: dwindling readership; ${ }^{2}$ new media competion, ${ }^{3}$ increased costs of doing business; ${ }^{4}$ increasing profit pressures; ${ }^{5}$ and a sense that newspapers had lost touch with readers and communities. ${ }^{6}$ This unsettling environment has defined the industry's mandate for change, and a fiery debate has emerged about the types of changes needed and why. ${ }^{7}$

This article reports the results of a four-year case study of changes at the St. Louis Post-Dispatch. Founded by Joseph Pulitzer and long considered a member of the U.S. "prestige press," the paper also faced many challenges at the end of the twentieth century. Its management responded in 1996 by hiring a new editor, Cole C. Campbell, whose stated goal was the "cultural transformation" of the news organization. ${ }^{8}$ Keys to the transformation were restructuring the newsroom from a beat system to a team system and embracing public journalism. These initiatives became cornerstones of change at newspapers nationwide in the late 1990s. ${ }^{9}$ Accordingly, the Post-Dispatch provided an excellent venue for studying newspaper organizational development initiatives.

Peter J. Gade is an assistant professor at the University of Oklahoma, and Earnest L. Perry is an associate professor at the University of Missouri. The authors wish to thank Keith Sanders and George Kennedy of the University of Missouri School of Journalism for their contributions to this study.

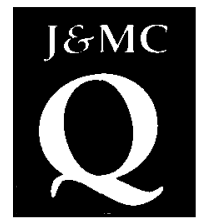

JEMC Quarterly Vol. 80, No. 2 Summer 2003 $327-347$ (C2003 AEJMC 
The data, a compilation of four surveys administered in the autumns of 1996-1998 and 2000, help explain the challenges newspapers face as they re-examine their mission in a dynamic media marketplace and the management difficulties of leading and implementing cultural change.

Literature

Review
Organizational Development. Organizational development(OD), the study of how organizations evolve, learn, and adapt, ${ }^{10}$ attracted the interest of U.S. scholars and corporate managers in the late twentieth century as the changing global marketplace threatened U.S. dominance. ${ }^{11}$ Lewin was among the first scientists to explain organizational dynamics when he described the process as "unfreezing, changing, refreezing." 12 Most theorists have conceived organizations as mechanisms that value "simplicity in motion" and homeostasis. ${ }^{13}$ Berquist contended this is a faulty metaphor in the postmodern world, and suggested viewing organizations as liquids, containing elements of stability and change "poised on the edge of order and chaos."14

Kanter wrote that companies that value "innovation" are better placed to use employee creativity to compete in changing environments. Innovative companies are "integrated"; they avoid "overspecification" and create opportunities for fresh thinking across organizational boundaries. ${ }^{15}$ Drucker extended this concept into what he calls the "knowledge organization," which utilizes employee knowledge as the organization's most valued resource, flattens the organizational hierarchy, and implements a team-based workplace with shared decision making. ${ }^{16}$

Because organizations vary in size, resources, and goals, OD research has usually focused on one organization at a time and on sitespecific variables. ${ }^{17}$ The interaction of change-related variables produces a chain of change-stimulating-change that makes the change process difficult to measure, and some scholars acknowledge a situation-bysituation approach makes theory-building more difficult. ${ }^{18}$

Most organizational development initiatives are attempts to change organizational culture, or an organization's way of doing things - its customs. It is a combination of macro (e.g., values and beliefs) and micro (e.g, roles, practices, and procedures) variables that give meaning to organizational life. Some scholars contend that the values and beliefs that support an organizational culture can be changed by focusing on the tangible (micro) variables that define daily life in the organization. ${ }^{19}$ Van Maanen and Barley suggest that cohort work groups create "occupational communities" that sustain relatively unique work cultures. Occupational communities develop because they seek "self control" - the autonomy to define the occupation's work culture. ${ }^{20}$

Many organizational development initiatives strive to create a "culture of contribution," where power and accountability are shared in ways that allow companies to respond quickly to challenges and opportunities. ${ }^{21}$ "Empowerment-oriented" leadership shares decision making, shows concern for employees, and is flexible. This "supportive management" style contributes to an organizational culture characterized by "cooperation, collaboration and concern for employee well-being. " 22 However, creating this culture has been more difficult in 
the United States than other nations because workers, especially professionals, value individualism and often express it in counterproductive ways. ${ }^{23}$

Managers often misunderstand resistance to change and perceive employees who resist as problems. Resistance, however, can be a rational response from employees who see themselves pushed in conflicting directions. Change creates losses for employees-their routines, some values, and the emotional loss of destroying what was. ${ }^{24}$ Accordingly, a large body of OD scholarship indicates that changing an organization's culture is not easily accomplished, and understanding the need to change is often not enough to convince employees, and even members of management, to accept change. ${ }^{25}$

Team-based Organizational Structures. Organizational scholars agree that team-based work is integral to innovative organizations. Teams create flatter (less vertical) hierarchies that empower employees with fewer and less rigid organizational boundaries. ${ }^{26}$ The team structure requires a new management philosophy that Hirschhorn called "managing the boundary," communicating company needs to the team and team needs to the company. Managers must learn to encourage team members to respond creatively to enhance team performance. ${ }^{27}$ Team members must take more responsibility for their work, which frustrates employees who operate under ingrained "schemas" of vertically structured systems. ${ }^{28}$

$O D$ Newspaper Research. Gentry observed change initiatives at a small California daily and identified variables essential for successful newspaper change: pre-change analysis to determine extent and type of changes needed; employee participation in drafting initiatives; mission statements; flexible strategies; and communication explaining the need to change, a vision of the future, and new expectations. ${ }^{29}$ In a subsequent study of six newspapers experimenting with change, Gentry found management thought it was doing a better job than the staff thought it was doing on all ten elements of change the study addressed. ${ }^{30}$ Gade found newspaper managers initiating change thought they led the process in accordance with OD literature. However, rank-and-file thought management was inflexible, authoritarian, and did not involve rank-and-file in planning change. Management acknowledged an unclear vision and breakdown of trust with rank-and-file. ${ }^{31}$

In research spanning three decades, Weaver and Wilhoit found in 1992 that journalists perceived less work autonomy than in previous decades, and this loss was a substantial factor in declining job satisfaction..$^{32}$ A study of management styles found that editors and reporters were about equally likely to view managers at their paper as "authoritarian" (as opposed to "democratic"); however, reporters tended to perceive the style as "too authoritarian," while editors characterized it as "about right." 33 Several studies have found journalists are more open-minded toward change and report higher job satisfaction when change is tied to pursuit of journalistic, not business, goals. ${ }^{34}$ However, a study of news, advertising, and circulation department heads found news editors significantly more likely to say more cooperation between departments is needed. The researcher concluded that news managers 
exhibit a "surprising sensitivity" to market-oriented concepts. ${ }^{35}$ Regarding technology driven-change, Singer found newspaper reporters and editors expected new media technology to modify their jobs, but not fundamentally change them. She concluded fundamental journalism values are "more important and more enduring." 36

Team-based newspaper reporting increased dramatically in the 1990s. A 1999 study found that $37 \%$ of newspapers surveyed used a team system, and 53\% with more than 100,000 circulation used teams. Only $8 \%$ had teams in $1992 .{ }^{37}$ Lewis concluded that newspaper team work requires employees to be flexible and learn a variety of tasks so teams can react to the marketplace. ${ }^{38}$ One study found that a team produced more coverage on the same topic than the beat system had, and the team stories got more prominent play in the paper. The researcher concluded team-based newsrooms represent a realignment of resources that may have important consequences for content. ${ }^{39}$ However, Neuzil, Hansen, and Ward found most journalists working in teams thought they had less authority and less success getting their story ideas into the paper. ${ }^{40}$ The researchers concluded the team system might be "a poor model for newsrooms and other jobs where creativity and certain professional standards are important." 41

Public Journalism. Public journalism, also called civic journalism, is a reform movement that gained momentum in the 1990s. Journalistic social responsibility is broadened into an active role, with journalism becoming a catalyst for the revival of public life by promoting citizen engagement, dialogue, and problem solving. ${ }^{42}$ Merritt insisted that publicjournalism requires journalists to abandon several traditional practices: valuing conflict as the primary story narrative, maintaining an adversarial role with institutions, treating readers as audiences instead of participants, and insisting that journalism credibility comes from detachment. ${ }^{43}$ The term "civic journalism" has been found to carry "semantic baggage," eliciting support or criticism without contemplation. ${ }^{44}$ Critics of public journalism contend its focus on community connections and solutions can easily compromise media independence and credibility ${ }^{45}$ Others have said that the movement is a response to increasingly profit-driven corporate media. However, even public journalism proponents acknowledge its eye on the marketplace. Merritt wrote, "People engaged in public life ... are avid consumers of the journalism product." ${ }^{\prime 6}$

Public Journalism and Team-based Newsroom Structures. The beat system of reporting is organized by institutions (government, schools, police, etc.), which public journalism proponents have said takes the newspaper away from reader interests. The team-based system, often organized by topic areas identified by readers, is conceived to empower journalists and readers, who become an important part of creating the news agenda. This dual empowerment reinforces the public journalism model that journalists and citizens share common goals. ${ }^{47}$ The editor of the (Columbia, S.C.) State said teams helped create a culture that nurtured public journalism. The team system and public journalism "involve breaking down walls and creating dialogue where it wasn't before. So many of the principles are exactly the same." 48 
In August 1996, Pulitzer Publishing Company CEO Michael Pulitzer introduced Cole C. Campbell as the new editor of the St. Louis Post-Dispatch, hailing Campbell as the clear choice because of his unique combination of journalistic skills, business acumen, leadership, and vision. ${ }^{49}$ Campbell, previously editor of the Norfolk Virginian-Pilot, brought to St. Louis a record of newsroom innovation. In Norfolk, Campbell established himself as a vocal advocate of newspaper industry change, and he led initiatives that included restructuring the newsroom into topic teams and training in public journalism. ${ }^{50}$ By the time he left Norfolk for the Post-Dispatch, the Virginian-Pilot had institutionalized its public journalism approach more than any U.S. newspaper. ${ }^{51}$

In the first half-decade of the 1990s, circulation at the PostDispatch dropped from 382,000 to 320,000 , and the paper, with a reputation of a liberal editorial voice in the Pulitzer tradition, was perceived as out of step with its readers, many of whom were part of an increasingly conservative suburban population..$^{52}$ The New York Times reported Campbell was hired to revive the flagship Pulitzer publication, quoting Publisher Nicholas Penniman IV: "In the last five years we have saved our way to prosperity. We have renegotiated our labor contracts, squeezed from the cost side, and it is clear that you can only grow by shrinking for so long. At some point you have to go out and get more readers and advertising dollars. ${ }^{\prime 53}$

Campbell became only the fifth editor in the Post-Dispatch's 117year history, and only the second whose last name was not Pulitzer. But his tenure as editor was to last just three-and-a-half years. In April 2000, Campbell's resignation, announced at a hastily called staff meeting, "constituted a real bombshell" in the newsroom. ${ }^{54}$ However, for the sixmonth period ending 31 March 2000, the Post-Dispatch had the secondhighest circulation loss, $3.4 \%$, of the twenty largest U.S. newspapers, and circulation was below $300,000(294,187)$ for the first time since $1982 .{ }^{55}$

Campbell on Newsroom Cultural Change. Campbell has contended that a problem with U.S. journalism is its "judgmental" culture, and journalism would be better served by a "collaborative" culture. If newspapers kept a keener eye on readers and the marketplace, then the newsroom would work more closely with the business side of the organization, with each having the same goal-a product that matters. Campbell called this culture of collaboration the best opportunity for "colonizing the rest of the company" with the values of the newsroom. ${ }^{56}$

Campbell wrote that some of journalists' basic beliefs must change if journalism is to help communities work through their problems. ${ }^{57} \mathrm{He}$ suggested two ways to "radically transform" journalism..$^{58}$ First, citizens would be better served if journalists viewed social institutions and government agencies not as sources of news but as resources for problem solving (Campbell's emphases). The other ideal was to move journalism away from a description of the present and toward the imagination of a better alternative. He wrote that imagination contributes to empathy and understanding of alternative realities. 
Critical Incidents. The 1997 St. Louis mayoral campaign was the city's first in which the two leading candidates were African American. University of North Carolina journalism professor Chuck Stone was hired as reader advocate and responded to readers' questions in a weekly column sent e-mail from North Carolina, 900 miles from St. Louis. The distance brought criticism from readers and inside the newsroom. The New York Times quoted the Post-Dispatch city hall reporter as saying Stone, an African American, was made reader advocate to appease the African-American community. ${ }^{59}$ The reporter was concerned the public would perceive the Post-Dispatch did not have confidence in her to cover the election objectively.

During Campbell's first year, a new tier of editors was created. Some came from Norfolk, and several middle-level editors at the PostDispatch were promoted. Also in 1997, the paper joined the St. Louis Regional Commerce and Growth Association and the William T. Kemper Foundation in commissioning a development report on the St. Louis region. The report ran as a series under the lead story headline " $\mathrm{A}$ Call to Action," calling Campbell one of America's leading public journalists, and reporting the Post-Dispatch would and should be deeply involved with the region's revitalization. ${ }^{60}$

The year-long process of restructuring into a team-based newsroom began in 1998. Consultants were hired, including Richard Harwood, with whom Campbell worked in Norfolk. The $\$ 250,000$ Harwood Initiative included seminars with a "leadership group" with the goal of thinking differently about gathering and presenting the news. ${ }^{61}$ Interdepartmental teams (members from news and business departments) worked on recruiting, hiring, developing an identity for the newspaper, understanding customers, and identifying problems that would stall initiatives. ${ }^{62}$ The number of newsroom jobs was not reduced; however, teams redefined or renamed many jobs, in essence eliminating numerous mid-level editors' positions and nineteen general assignment reporters. A majority of reporters and editors had to reapply for positions as team members or leaders. ${ }^{63}$ Teams set goals and drafted mission statements. Campbell believed teams would put journalists back on the street and create more community reporting. ${ }^{64}$

In April 1999, a new section, Imagine St. Louis, appeared in the Sunday newspaper replacing the news analysis section. Each week, the section front page led with a story about an issue identified as a pressing priority; examples included illiteracy, immigration, the St. Louis arts community, and plans for a new bridge across the Mississippi River. Section features included a "Conversations" column of reader letters, an "Issues Map" with key questions and citizen perspectives on the issue, and a "Who Calls the Shots" listing of decision makers and resources for citizen involvement. The Post-Dispatch collaborated with local television and radio outlets to create and promote weekly programs. Campbell envisioned Imagine St. Louis as a vehicle for citizens to affect news coverage and community action. ${ }^{65}$

In March 2000, a group of senior Post-Dispatch journalists gave Publisher Terrance Eggers (who replaced Penniman in 1999) a list of nineteen staff members, some of the paper's most respected and 
awarded journalists, who had left the paper in the previous eighteen months. The staffers told Eggers that the departures were tied to Campbell's change initiatives and the exodus would continue. Less than two weeks later, Campbell resigned and became a fellow at the Poynter Institute. He has been an associate of the Kettering Foundation since 2001, overseeing research in journalism and democracy. ${ }^{66}$

In sum, organizational development literature provides a theoretical framework for understanding the change process. OD research suggests that innovative organizations empower employees and break traditional barriers. Management empowers employees by involving them in change, seeking their opinions, and valuing their experience and knowledge. Empowerment-oriented leadership prepares employees for change by communicating reasons for change and sharing decision making; trust is built by showing concern for employees. Working in teams is essential to leveraging employee knowledge and innovation. The team system flattens organizational hierarchies, redefines jobs, creates fewer mid-level managers, and reallocates newsroom resources. Team work requires more collaboration among workers, and U.S. journalists have been shown to value their autonomy. Public journalism is a reform movement that requires abandoning several traditional journalistic norms to create more citizen-based reporting. Its practice has been associated with team-based newsrooms, and both proponents and critics acknowledge its market-driven rationale. Journalists have indicated higher job satisfaction if change is related to pursuing journalistic (not business) goals.

This understanding of organizational development, newsroom structural change, public journalism, and Campbell's change agenda shaped the following research questions:

RQ1: What were the newsroom employees' perceptions of the organizational development initiatives during the period of change?

RQ2: What were newsroom employees' perceptions of the newsroom structure during the period of change?

RQ3: What were the newsroom employees' perceptions of public journalism during the period of change?

The period of change is defined as Campbell's tenure as editor. The researchers administered surveys during one-day visits to the downtown newsroom in the autumns of 1996,1997, 1998, and 2000. ${ }^{67}$ The visit was made on a mid-week day and every news employee working that day was asked to complete a survey. ${ }^{68}$ During this period, the news staff, excluding bureaus, fluctuated from 270 to 300 people; approximately 200 worked in the downtown newsroom during the day. ${ }^{69}$ The first survey was administered a week before Campbell started work. Journalists had been introduced to the new editor during a staff 
meeting and had been able to find out about him through the media, including their own paper, prior to his arrival. Studying their perceptions about need for change and their attitudes toward changes expected under the new editor created a baseline of measures for subsequent surveys. The 1997 and 1998 surveys measured employee attitudes as initiatives were developed and implemented. The 2000 survey, conducted six months after Campbell's resignation but prior to a new editor being named, provided a final measure of attitudes about the change process.

The core of the survey instrument remained the same over four years. Statements measured level of agreement or disagreement along a seven-point intensity scale. In 1997, several statements about public journalism were added to the survey, and in 2000 , statements related to the Imagine St. Louis section and team-based structure implemented in 1999 were added. To reflect the timing of the surveys, statement wording was adjusted slightly. For example, a 1996 statement was: Under the new editor, I expect the paper will cover government as it always has; in 1997 and 1998, this statement read: Under the current editor, the paper covers government as it always has; in 2000, it read: Under the former editor, the paper covered government as it always had.

Factor analysis was used to assist in constructing measures of organization development, newsroom structure, and public journalism. The statements were coded so agreement with a statement reflected a positive attitude toward the construct. To allow for annual construct comparisons, the means of the statements in the constructs were averaged to create construct quotients. Reliability coefficients (Cronbach's alpha) for the constructs come from all available data: organizational development, measured by seven statements (.77); organizational structure, measured with four statements (.76); public journalism, measured with seven statements (.72).

The number of responses for each year was: 74 in 1996; 124 in 1997 (59 also responded in 1996); 108 in 1998 (80 responded previously); 121 in 2000 ( 68 responded previously). Because the research sought sensitive information about employee-management relationships, no effort was made in 1996 to identify respondents for a panel study. The measure of repeat respondents relied on respondent self-reports. ${ }^{70}$ However, there were no significant differences between repeat respondents and all respondents on any of the constructs for any of the years. ${ }^{71}$ The data reported in the tables are from all respondents.

\section{Results}

The first research question explored perceptions about organizational development and how they changed over the four years. An ANOVA test of the organizational development quotient shows no significant differences the first three years $(1996,1997,1998)$; however, in 2000 respondents became significantly (Tukey post hoc test) more negative toward OD (see Table 1). In 1996, there was optimism about change and the way it would be implemented. Respondents expected to work more closely with advertising and circulation departments, but anticipated the new editor would not make changes right away and 


\section{TABLE 1}

Organizational Development Construct (7 Statements, Cronbach's alpha $=.77$ ) ANOVA Tests Measuring Change over Time

Items were arrayed on 7 -point scales, ranging from 1 (strongly disagree) to 7 (strongly agree), with 4 neutral.

\begin{tabular}{|c|c|c|c|c|c|c|}
\hline \multirow{2}{*}{ OHO } & \multirow{2}{*}{\multicolumn{2}{|c|}{$\begin{array}{c}1996 \\
\text { Mean s.d. } \\
N=74\end{array}$}} & \multicolumn{2}{|c|}{1997} & 1998 & \multirow{2}{*}{$\underset{N=121}{2000}$ Mean } \\
\hline & & & $\begin{array}{l}\text { Mean } \\
N=\end{array}$ & $\begin{array}{l}\text { s.d. } \\
24\end{array}$ & $\begin{array}{l}\text { Mean s.d. } \\
N=108\end{array}$ & \\
\hline $\begin{array}{l}\text { Organizational Development Quotient } \\
\text { (mean of the seven statements) }\end{array}$ & $3.91 \mathrm{a}$ & .77 & $3.81 \mathrm{a}$ & 1.0 & $3.97 a \quad 1.1$ & $2.84 b^{* *} \quad .89$ \\
\hline
\end{tabular}

Statements

The newsroom has worked more closely with the advertising and circulation

4.58ab $1.6 \quad 4.59 \mathrm{ab} \quad 1.4 \quad 5.00 \mathrm{a}^{* *} 1.3 \quad 4.18 \mathrm{~b}^{* *} 1.3$

departments under the current editor.

The current editor did not make changes until he had a feel for the newsroom and the city.

I think the current editor has been sensitive to employees' concerns.

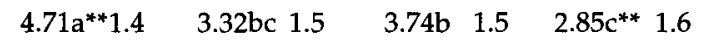

The newsroom staff has been open-minded about changes.

$\begin{array}{lllllll}4.18 \mathrm{a} & 1.1 & 3.69 \mathrm{a} & 1.8 & 3.59 \mathrm{a} & 1.8 & 2.16 \mathrm{~b}^{* *} 1.8 \\ 4.28 \mathrm{a} & 1.5 & 4.28 \mathrm{a} & 1.6 & 4.05 \mathrm{a} & 1.5 & 2.88 \mathrm{~b}^{* *} 1.7 \\ & & & & & & \\ 3.92 \mathrm{a}^{* *} 1.6 & 3.30 \mathrm{~b} & 1.7 & 3.21 \mathrm{~b} & 1.7 & 2.04 \mathrm{c}^{* *} 1.5\end{array}$

The current editor values the experience and knowledge of long-time Post-Dispatch employees.

The current editor has sought opinions from newsroom workers about how to $2.73 a^{* *} 1.7 \quad 3.98 b \quad 2.0$ $4.40 \mathrm{~b}^{* *} 1.9 \quad 2.93 \mathrm{a}^{* *} 1.8$ improve the newspaper and newsroom efficiency.

Management has done a good job preparing newsroom employees for

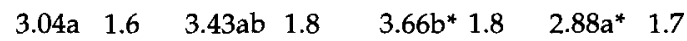
changes that have taken place in the past year.

$a, b, c:$ Means with common lowercase letters are not significantly different $(p<.05)$ from one another by a Tukey post hoc test.

${ }^{*} p<.05 ;{ }^{* *} p<.01$

would be sensitive to their concerns. They viewed the staff as openminded about changes the new editor would bring.

By 1997 much of the optimism had eroded, and there were significant differences from 1996 to several statements in the construct, although responses were not strongly negative overall. Respondents remained open-minded, but indicated that changes had begun before the new editor had a feel for the newsroom and city, and they began to perceive that veteran Post-Dispatch journalists were not highly 


\section{TABLE 2}

Newsroom Structure Construct (4 Statements, Cronbach's alpha $=.76$ ) ANOVA Tests Measuring Change over Time

Items were arrayed on 7-point scales, ranging from 1 (strongly disagree) to 7 (strongly agree), with 4 neutral.

$\begin{array}{cccc}1996 & 1997 & 1998 & 2000 \\ \begin{array}{c}\text { Mean s.d. } \\ N=74\end{array} & \begin{array}{c}\text { Mean s.d. } \\ N=124\end{array} & \begin{array}{c}\text { Mean s.d. } \\ N=108\end{array} & \begin{array}{c}\text { Mean s.d. } \\ N=121\end{array}\end{array}$

Newsroom Structure Quotient

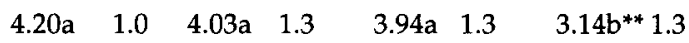

(mean of the four statements)

Statements

Working in teams is a good idea.

$\begin{array}{lllllll}4.69 \mathrm{a} & 1.5 & 4.76 \mathrm{a} & 1.6 & 4.24 \mathrm{a} & 1.7 & 3.42 \mathrm{~b}^{* *} 2.0\end{array}$

Newsroom structural changes under the

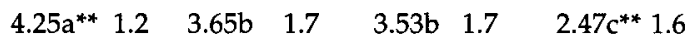
current editor have helped the paper practice better journalism.

I think newsroom resources-the human, technical and financial support-for

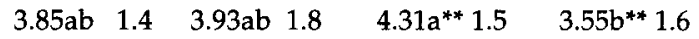
practicing journalism have increased under the current editor.

I have benefited from changes in

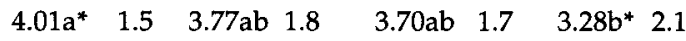
newsroom structure under the current editor.

$a, b, c:$ Means with common lowercase letters are not significantly different $(p<.05)$ from one another by a Tukey post hoc test.

${ }^{*} p<.05 ; * * p<.01$

valued. The 1998 data show few changes from 1997, and the OD quotient is statistically neutral. The 1998 survey was taken when the paper had completed a self-study for reorganization and restructuring to teams was due to begin. Responses reflect this change-related work, with strong agreement that the newsroom was working more closely with non-news departments and agreement for the only time during the study that the editor sought employee opinions about improving the paper and newsroom efficiency. However, in 2000 there were consistent and strong negative responses toward OD. For the first time in the study, the staff indicated it was no longer openminded toward change, and the strongest disagreement was that the editor was sensitive to employees' concerns and valued the experience and knowledge of veteran journalists. Journalists also indicated they 
were no longer being asked how to improve the newspaper and newsroom operation.

The second research question probed employees' attitudes toward changes in newsroom structure. Respondents had a slightly positive attitude in 1996, were close to neutral in 1997 and 1998, and became negative in 2000. An ANOVA test showed no significant differences among measures for the first three years of the study and significantly more negative attitudes in 2000 (see Table 2).

The 1996 data indicate that respondents were optimistic about working in teams and the prospects of structural changes improving journalism quality. The optimism about working in teams remained in 1997; however, respondents showed moderate disagreement that structural changes improved the quality of journalism (the newsroom had not yet become team-based, but a new tier of editors had been created). In 1998 there were no significant differences on any of the statements in the construct. It becomes clear that journalists liked the idea of working in teams until they actually restructured into a teambased newsroom. The 2000 data revealed significantly more negative attitudes toward three of the four statements in the construct, including the idea that restructuring led to better journalism.

The staff worked in teams for the last year of Campbell's editorship. Six statements about teams were added in 2000 to provide a broader and more theoretical measure of what reorganization meant, and respondents recorded negative attitudes toward all the statements (means noted parenthetically; not shown in tables). They disagreed the team system gave them more job-related authority (3.11) or autonomy (3.19); they also did not perceive better success getting their story ideas into the paper (3.35). Beyond this, respondents disagreed teams did better at story development (3.02), got more breaking news in the paper (2.26), or improved product quality (2.45).

The third research question explored perceptions about public journalism and values associated with it. This construct was created after several statements were added to the survey in 1997. The data indicate that the staff had negative attitudes toward public journalism all three years the construct was measured (see Table 3); however, an ANOVA test shows respondents' attitudes were significantly more negative in 2000 .

The responses show that journalists perceived their news values were changing in some ways to support a public journalism model, but respondents held some reservations about public journalism that became clearer as time passed. They agreed all three years that the newspaper was more active in resolving community issues and was reporting on government differently than it had. However, journalists were unsure whether public journalism was genuinely focused on journalism, indicating consistent (albeit slight) agreement all three years that public journalism is more of an economic response to the challenges facing the paper than an attempt to practice better journalism. By 2000, the staff reported strong disagreement that the Post-Dispatch can better contribute to the St. Louis area by practicing public journalism and disagreed even more strongly that its practice improved newsroom morale. These 


\section{TABLE 3}

Public Journalism Construct (7 Statements, Cronbach's alpha $=.72$ ) ANOVA Tests Measuring Change over Time

Items were arrayed on 7-point scales, ranging from 1 (strongly disagree) to 7 (strongly agree), with 4 neutral.

\begin{tabular}{ccc}
$\operatorname{Mean}_{N=124}^{1997}$ s.d. & \multicolumn{2}{c}{2000} \\
& Mean s.d. & Mean \\
$N=108$ & $N=121$
\end{tabular}

Public Journalism Quotient

$\begin{array}{lllll}3.76 a & .90 & 3.86 a & .90 & 3.24 b^{* *} \quad .88\end{array}$

(mean of the seven statements)

Statements

$\begin{array}{lllllll}\text { The newspaper has taken a more active role } & 4.84 \mathrm{a} & 1.50 & 4.82 \mathrm{a} & 1.60 & 4.66 \mathrm{a} & 1.50\end{array}$ resolving community issues under the current editor.

The paper has continued to cover government as it always has.

Public journalism is more an economic response to the challenges facing the Post-Dispatch than an attempt to practice better journalism.

The Post-Dispatch can better contribute to the St. Louis area by practicing public journalism.

The practice of public journalism has improved newsroom morale.

Public journalism projects have created more resources for the newsroom.

$\begin{array}{llllll}3.81 \mathrm{a} & 1.40 & 3.70 \mathrm{a} & 1.50 & 3.17 \mathrm{~b}^{* *} & 1.50\end{array}$

Under the current editor, there is more good news in the paper.

$\begin{array}{llllll}3.91 \mathrm{a} & 1.90 & 3.98 \mathrm{a} & 1.80 & 2.81 \mathrm{~b}^{* *} & 1.80\end{array}$

$\begin{array}{llllll}2.92 \mathrm{a} & 1.40 & 3.12 \mathrm{a} & 1.40 & 1.88 \mathrm{~b} * & 1.30\end{array}$

$a, b, c:$ Means with common lowercase letters are not significantly different $(p<.05)$ from one another by a Tukey post hoc test.

${ }^{*} p<.05 ;{ }^{* *} p<.01$

results can be better understood when considered with statements added to the 2000 survey regarding the Imagine St. Louis section, which began in 1999 (no table shown). The staff agreed strongly that Imagine St. Louis was an example of public journalism as envisioned by the editor (6.11), but disagreed almost as strongly that the section improved the newspaper (2.57).

Discussion

Responses over four years show initial optimism toward change and the new editor, followed by moderately negative attitudes in 1997 and 1998 , which by 2000 became broad-based dissatisfaction. When the 
study began, many Post-Dispatch journalists anticipated change as an opportunity to improve both the newsroom operation and quality of the newspaper. The data suggest that by 2000 respondents perceived that change initiatives had accomplished neither. Campbell's vision of a collaborative, team-based newsroom practicing public journalism confused many journalists and failed to win broad-based support.

Organizational scholars contend that successful postmodern companies are integrated, breaching traditional barriers to nurture creativity and leverage employee knowledge. Team-based work, with flatter corporate hierarchies and shared decision making, is a key enabling structure for innovation. However, respondents in this study, working in both interdepartmental and newsroom teams, found little about the team-based structure that was empowering. The staff spent months in 1998 discussing, training, and preparing to implement a team-based structure before phasing it in over a six-month period. This preparation gave journalists a chance to learn the team system and have input in its creation; yet, after they had worked in it a year, they no longer thought teams were a good idea. Journalists found the system provided less individual autonomy and authority over their work, which is contrary to theory but consistent with one of the few studies of team-based newsrooms. ${ }^{72}$ It appears an important question is whether the newsroom culture-rooted in individualism that values personal resourcefulness, skill, and creativity as measures of professionalism-lends itself to the collaborative demands of a teambased structure.

Another view of the impact of teams acknowledges that breaching traditional organizational barriers to many journalists means becoming more market-driven. ${ }^{73}$ The "wall" that separated news and business sides of newspapers has been weakened by more aggressive attempts to attract readers. Respondents were asked to work in interdepartmental teams to better understand customers and develop the paper's identity, as well as to create newsroom teams responsible for aligning content with reader interests. These changes apparently confused journalists about the values associated with change. Respondents consistently agreed over the course of the study that public journalism was more an economic response to challenges facing the newspaper than an attempt to practice better journalism. The idea that an integrated, team-based news organization is perceived by newspaper journalists as a threat to their journalistic values and autonomy helps explain why journalists have been labeled resistant to change and suggests their resistance is indeed rational. ${ }^{74}$

An interesting question is to what extent in 2000 was respondents' negativity toward teams and public journalism reflective of their attitudes toward those concepts or Campbell's approach to managing change. Although the data cannot completely answer this question, journalists expressed open-mindedness through more than two years of Campbell-led initiatives. The 1998 data show a staff focused on restructuring and anticipating benefits associated with change. Only after respondents failed to see a connection between change and a better newspaper, and they perceived that change initiatives would continue 
to be pushed forward without the value of their input and experience, did they reject Campbell's attempt at cultural transformation.

As a case study, the ability to generalize the findings is limited. The constructs in this study are relevant to change efforts at newspapers across the country, but a more basic issue is the lack of established measures for studying change. Measures need further refinement and testing if scholars and media managers are to better understand the values that define their newsroom cultures and the process of organizational development. This said, there was minimal instrument decay over the study's four years. All the statements in the constructs remained relevant throughout the study, and even as attitudes changed, the alpha measures for all constructs stayed above .70 .

This study sought over a period of four years to answer how respondents try to make sense of change, conceive it in regard to their individual place in the organization, and integrate it with their sense of journalistic norms and professionalism. The study contributes to existing knowledge in several ways. Change is a "process," and this study's longitudinal approach revealed the ebb and flow of change, its complexity and the inter-related nature of the organizational, journalistic, and management variables in a manner single "snapshot" studies cannot. Second, scholars have noted the need to understand the climate and culture of an organization prior to embarking on organizational development programs. ${ }^{75}$ This study collected data a week before Campbell assumed daily duties as editor, and responses from this 1996 survey proved to be good predictors of what the staff expected from change, the issues important to them, and their subsequent attitudes. This seldom-used approach can provide media managers valuable information as a "cultural audit" before embarking on change. Third, as media audiences continue to fragment in an environment that offers the public more options and control, ${ }^{76}$ it is likely that traditional sources of news and information will continue experimenting with change to maintain and attract audiences. This study adds to a small body of research that suggests the benefits of integrated, team-based organizations are not apparent to newspaper journalists, who value their independence and perceive the importance of maintaining a distance from the business interests of the company.

Appendix and Notes follow. 
APPENDIX

Respondent Demographics

Variable

$\begin{array}{lrcc}1996 & 1997 & 1998 & 2000 \\ N=74 & N=124 & N=108 & N=121\end{array}$

Race: White

Minority

No response

$54(74 \%) \quad 98(79 \%) \quad 74(69 \%) \quad 82(68 \%)$

$8(11 \%) \quad 10(8 \%) \quad 13(12 \%) \quad 11(9 \%)$

$11(15 \%) \quad 16(13 \%) \quad 21(19 \%) \quad 28(23 \%)$

Job

$\begin{array}{ll}\text { Title: } & \text { Top Managers } \\ & \text { Mid Managers } \\ & \text { News Staff } \\ & \text { No response }\end{array}$

$\begin{array}{cccc}5(7 \%) & 12(10 \%) & 6(6 \%) & 24(20 \%) \\ 31(42 \%) & 48(39 \%) & 44(41 \%) & 23(19 \%) \\ 33(45 \%) & 55(44 \%) & 44(41 \%) & 50(41 \%) \\ 4(6 \%) & 9(7 \%) & 14(13 \%) & 24(20 \%)\end{array}$

Gender: Female

Male

No response

$\begin{array}{cccr}28(38 \%) & 38(31 \%) & 40(37 \%) & 46(38 \%) \\ 45(61 \%) & 78(63 \%) & 63(58 \%) & 67(55 \%) \\ 1(1 \%) & 8(6 \%) & 5(5 \%) & 8(7 \%)\end{array}$

Income

Level: $\quad \$ 20-29,999$

$\$ 30-49,999$

$\$ 50-69,000$

$\$ 70,000+$

No response

$\begin{array}{rrrr}5(7 \%) & 9(7 \%) & 4(4 \%) & 1(1 \%) \\ 13(18 \%) & 31(25 \%) & 29(27 \%) & 30(25 \%) \\ 43(58 \%) & 72(58 \%) & 65(60 \%) & 49(41 \%) \\ 12(16 \%) & 12(10 \%) & 5(4 \%) & 17(14 \%) \\ 1(1 \%) & 0 & 5(4 \%) & 24(20 \%)\end{array}$

Mean s.d. Mean s.d. Mean s.d. Mean s.d.

Years experience at the Post-Dispatch

14.1

$8.4 \quad 12.7$

$8.9 \quad 14.3$

$\begin{array}{lll}7.8 & 13.6 & 11.0\end{array}$

Age

$44.6 \quad 10.2$

42.1

10.4

$44.1 \quad 10.0$

$43.5 \quad 10.5$ 
1. John C. Merrill, The Dialectic in Journalism (Baton Rouge: LSU Press, 1989), 4-6.

2. Robert Picard and Jeffrey Brody, The Newspaper Publishing Industry (Boston: Allyn and Bacon, 1997).

3. Philip Evans and Thomas Wurster, "Strategy and the New Economics of Information," Harvard Business Review, September/October 1997, 71-82.

4. John Morton, "Newsprint Prices: Rising Again?" American Journalism Review, March 1998, 56.

5. Neil Hickey, "Money Lust," Columbia Journalism Review, July/ August 1998, 28-36. For an overview of the growth of a businessminded newsroom culture, see Doug Underwood, When MBAs Rule the Newsroom (New York: Columbia University Press, 1993). For the impact of public ownership on profit goals, see Paul Hirsch and Tracy Thompson, "The Stock Market as Audience," in Audience Making: How the Media Create an Audience, ed. James Ettema and D. Charles Whitney (Thousand Oaks, CA: Sage, 1994), 142-158.

6. Most of the literature on public journalism addresses this topic. See, for example, Jay Rosen, What Are Journalists For? (New Haven: Yale University Press, 1999); Davis Merritt, Public Journalism and Public Life, 2d ed.(Mahwah, NJ: Erlbaum, 1998).

7. George Sylvie and Patricia Witherspoon, Time, Change and the American Newspaper (Mahwah, NJ: Erlbaum, 2002), 3-12.

8. Cole C. Campbell, "Cultural Transformation," (handout distributed at seminar at the University of Missouri School of Journalism, Columbia, MO, 21 January 1998).

9. Ann B. Schierhorn, Fred Endres, and Carl Schierhorn, "Newsroom Teams Enjoy Rapid Growth in the 1990s," Newspaper Research Journal 22 (summer 2001): 2-15; Edmund B. Lambeth, Philip E. Meyer, and Esther Thorson, eds., Assessing Public Journalism (Columbia: University of Missouri Press, 1998); for a discussion about model team structures, how newsroom teams work and attempts to change journalists values, see Carl Sessions Stepp, "Reinventing the Newsroom," American Journalism Review, April 1995, 29-33; Alicia Shepard, "The Change Agents," American Journalism Review, May 1998, 42-49; Carl Sessions Stepp, "Reader Friendly," American Journalism Review, July/August 2000, 22-35.

10. Chris Argyris, Knowledge for Action: A Guide to Overcoming Barriers to Organizational Change (San Francisco: Jossey-Bass, 1993).

11. Rosabeth Moss Kanter, The Change Masters (NY: Simon and Schuster, 1983), 17. Peter Drucker has also expressed this idea in numerous writings, especially in relation to Japanese corporations. See, for example: Peter Drucker, Managing in a Time of Great Change (Dutton, NY: Truman Talley Books, 1995).

12. Kurt Lewin, "Frontiers in Group Dynamics," Human Relations 1 (June 1947): 5-41.

13. William Bergquist, The Postmodern Organization: Mastering the Art of Irreversible Change (San Francisco: Jossey-Bass, 1993), 3. 
14. Bergquist, The Postmodern Organization, 9.

15. Kanter, The Change Masters, 28-36.

16. Peter Drucker, Management Challenges for the 21st Century (NY: Harper Collins, 1999); for an overview of newspapers as knowledge organizations, see Sylvie and Witherspoon, Time, Change and the American Newspaper, 32-34.

17. Kim S. Cameron and David A. Whetten, eds., Organizational Effectiveness: A Comparison of Multiple Models (NY: Academic Press, 1983).

18. Kanter, The Change Masters, 293; in Argyris, Knowledge for Action, 52-55, he acknowledges the difficulty of theory-building but offers two organizational development models.

19. Benjamin Schneider, Arthur P. Brief, and Richard A. Guzzo, "Creating the Climate and Culture for Sustainable Competitive Advantage," Organizational Dynamics 24 (spring 1996): 7-19.

20. John Van Maanen and Stephen R. Barley, "Occupational Communities: Culture and Control in Organizations," in Research in Organizational Behavior, ed. Barry M. Staw and L.L. Cummings (Greenwich, CT: Jai Press, 1984), 287-365.

21. James R. Fisher Jr., "Envisioning a Culture of Contribution," Journal of Organizational Excellence 20 (winter 2000): 47-54.

22. Cameron M. Ford, "Creativity is a Mystery: Clues from Investigators' Notebooks," in Creative Action in Organizations, ed. Cameron M. Ford and Dennis A. Gioia (Thousand Oaks: Sage Publication, 1995).

23. Fisher Jr., "Envisioning a Culture of Contribution," 48.

24. Peter de Jager, "Resistance to Change," Futurist 35 (May/June 2001): 24-27.

25. Chris Argyris, Behind the Front Page (San Francisco: Jossey-Bass, 1974), 242-53; Argyris, Knowledge for Action, 52-55; see Chapter 10 of Kanter, The Change Masters, for a discussion of what makes a corporate culture and how to create a strategy for changing culture; Daryl $\mathrm{R}$. Connor, Managing at the Speed of Change (NY: Villard Books, 1992); Guiseppe Labianca, Barbara Gray, and Daniel J. Brass, "A Grounded Model of Organizational Schema Change During Empowerment," Organization Science 11 (March/April 2000): 235-57; de Jager, "Resistance to Change," 24-27.

26. Larry Hirschhorn, Managing in the New Team Environment (NY: Addison-Wesley, 1991); W. Alan Randolph, "Re-thinking Empowerment," Organizational Dynamics 29(2,2000):94-107; see Chapter 9 of Kanter, The Change Masters, for an overview on how teams work; for more general discussion of the merits of teams, Drucker, Managing in a Time of Great Change; Peter M. Senge, The Fifth Discipline: That Art and Practice of the Learning Organization (NY: Doubleday, 1990).

27. Hirschhorn, Managing in the New Team Environment, 15.

28. Labianca, Gray, and Brass, "A Grounded Model of Organizational Schema Change During Empowerment," 235.

29. James Gentry, "Analysis of Change at a Small Daily Newspaper" (Ph.D. diss., University of Missouri, 1993); Gentry, working with the American Press Institute, in 1996 created an unpublished model called 
"A Roadmap for Change," which further specified important change variables.

30. James Gentry, "Keys to Success: Change Survey Results," Change: Living It, Embracing It, Measuring It, Annual report of the American Society of Newspaper Editors Change Committee, 1997, 21.

31. Peter Gade, "Turbulent Times: A Study of Change in the Newspaper Industry" (Ph.D. diss., University of Missouri, 1999).

32. David H. Weaver and G. Cleveland Wilhoit, The American Journalist in the 1990s (Mahwah, NJ: Erlbaum, 1996), 105-121.

33. Cecilie Gaziano and David C. Coulson, "Effect of Newsroom Management Styles on Journalists: A Case Study," Journalism Quarterly 65 (winter 1988): 869-80.

34. Peter Gade, "Managing Change: Editors' Attitudes Toward Integrating Marketing, Journalism," Newspaper Research Journal 23 (spring 2002): 148-52; George L. Daniels and C. Ann Hollifield, "Times of Turmoil: Short- and Long-Term Effects of Organizational Change on Newroom Employees," Journalism \& Mass Communication Quarterly 79 (autumn 2002): 661-80; Keith Stamm and Doug Underwood, "The Relationship of Job Satisfaction to Newsroom Policy Changes," Journalism \& Mass Communication Quarterly 70 (autumn 1993): 528-41.

35. George Sylvie, "Departmental Influences on Interdepartmental Cooperation at Daily Newspapers," Journalism \& Mass Communication Quarterly 73 (spring 1996): 230-41.

36. Jane B. Singer, "Changes and Consistencies: Newspaper Journalists Contemplate Online Future," Newspaper Research Journal 18 (winter/spring 1997): 2-18.

37. Schierhorn, Endres, and Schierhorn, "Newsroom Teams Enjoy Rapid Growth in the 1990s," 6, 12.

38. Regina L. Lewis, "How Managerial Evolution Affects Newspaper Firms," Newspaper Research Journal 18 (winter/spring 1997): 103-125.

39. John T. Russial, "Topic-team Performance," Newspaper Research Journal 18 (winter/spring 1997): 126-44.

40. Mark Neuzil, Kathleen Hansen, and Jean Ward, "Twin Cities Journalists' Assessment of Topic Teams," Newspaper Research Journal 20 (winter 1999): 2-16.

41. Neuzil, Hansen, and Ward, "Twin Cities Journalists' Assessment of Topic Teams," 14.

42. Rosen, What Are Journalists For?; Merritt, Public Journalism and Public Life.

43. Rosen and Merritt have written extensively about journalistic practices that need revision. For a brief summary, see Davis Merritt, "Missing the Point," American Journalism Review, July/August 1996, 2931.

44. Michael McDevitt, Bob M. Gassaway, and Frank G. Perez, "The Making and Unmaking of Civic Journalists," Journalism $\mathcal{E}$ Mass Communication Quarterly 79 (spring 2002): 87-100; Peter Gade, Scott Abel, Michael Antecol, Hsiao-Yin Hsueh, Janice Hume, Jack Morris, Ashley Packard, Susan Willey, Nancy Fraser, and Keith Sanders, "Journalists' Attitudes Toward Civic Journalism Media Roles," Newspaper Research Journal 19 (fall 1998): 10-26. 
45. Don Corrigan, The Public Journalism Movement in America: Evangelists in the Newsroom (Westport, CT: Greenwood Publishing Group, 1999); William Woo, "Should the Press Be an Observer or an Actor in Public Affairs?" St. Louis Journalism Review, July/August 1995, 10. For a philosophical and historical critique of public journalism and its communitarian roots, see John C. Merrill, Peter J. Gade, and Frederick R. Blevens, Twilight of Press Freedom:The Rise of People's Journalism, (Mahwah, NJ: Erlbaum, 2001).

46. Merritt, Public Journalism and Public Life, 103; also see Rosen, What Are Journalists For?, Chapter 10 for the impact of corporate values on journalism; and Merrill, Gade, and Blevens, Twilight of Press Freedom, Chapter 7, for a discussion how public journalism is a good business strategy for newspapers.

47. Scott Johnson, "Public Journalism and Newsroom Structure," in Assessing Public Journalism, ed. Lambeth, Meyer, and Thorson, 12342.

48. Johnson, "Public Journalism and Newsroom Structure," 142.

49. Harry Levins, "Editor Arrives to Set a New Direction," St. Louis Post-Dispatch, 25 August 1996, sec. D. p. 1.

50. For an example of Campbell's advocacy of industry change, see: Cole C. Campbell, "Cole Campbell Offers an Open Letter to Critics H.L. Schwartz III and Frank McCulloch ... and They Respond," ASNE Bulletin, May 1995, 3. For an overview of change initiatives Campbell led in Norfolk, see: Art Charity, Doing Public Journalism (NY: Guilford Press, 1995); C. Conte, "Civic Journalism," CQ Researcher, 20 September 1996, 819-839; Rosen, What Are Journalists For?, 128-55.

51. Edmund Lambeth, "Public Journalism as Cultural Change, " in Assessing Public Journalism, ed. Lambeth, Meyer, and Thorson, 232-50.

52. Iver Peterson, "In St. Louis, Pulitzer Flagship in Search of Itself," the New York Times, 1 April 1996, sec. D, p. 1.

53. Peterson, "In St. Louis, Pulitzer Flagship in Search of Itself," sec. D, p. 1.

54. Alicia Shepard, "The End of the Line," American Journalism Review, July/August 2000, 44-51.

55. Christine Hawkins, "Post-Dispatch Circulation Falls Under 300,000," St. Louis Business Review, 29 May 2000, 21.

56. Campbell, "Cultural Transformation."

57. Cole C. Campbell, "Journalism as a Democratic Art," in The Idea of Public Journalism , ed., Theodore L. Glasser (NY: Guilford Press, 1999), xiii-xxix.

58. Campbell, "Journalism as a Democratic Art," xxv-xxvi.

59. Iver Peterson, "A Paper Goes Afar for a Look at Itself," the New York Times, 9 December 1996, sec. D, p. 9.

60. Neil Peirce and Curtis Johnson, "A Call to Action," St. Louis PostDispatch, 9 March 1997, sec. B, p. 1.

61. Shepard, "The Change Agents," 42-49.

62. Cole C. Campbell, "Newsroom Reorganization Objectives," Internal publication of the St. Louis Post-Dispatch, 7 October 1998.

63. Michael Sorkin and Phyllis Librach, "The Gospel According to Cole Campbell: Almost Everything You Wanted to Know about 
Reorganization but Were Afraid to Ask," Internal publication of the St. Louis Post-Dispatch, April 1999.

64. Sorkin and Librach, "The Gospel According to Cole Campbell," 1.

65. Cole C. Campbell, "Imagine a New Way of Thinking about What Matters Most," St. Louis Post-Dispatch, 11 April 1999, sec. B, p 1.

66. Cole C. Campbell, (personal communication, 18 December 2002).

67. No data were collected in 1999 because the researchers had moved from the Midwest and did not anticipate continuing the study.

68. An e-mail message was sent to the staff prior to each year's newsroom visit explaining briefly the study and that a survey would be administered. During the visits, researchers hand-delivered surveys to employee desks, where employees completed them over the course of the day and returned them to a collection point, a room adjacent to the newsroom. Employees who did not complete a survey were asked to return it. No more than ten surveys were returned uncompleted in any year.

69. Cheryl Laut, administrative assistant to the editor of the St. Louis Post-Dispatch (personal communication, 20 November 2002).

70. The researchers attempted to track repeat respondents so that comparative measures over time included only respondents who completed earlier surveys. The researchers relied on self-reports of respondents as a measure of prior participation in the study. In 1997, respondents were asked if they completed the survey in 1996. In 1998 the study was in its third year, and it was expected that some respondents would have difficulty recalling the specific years in which they participated. Accordingly, in 1998 respondents were asked three yes-no questions: Did you complete one of our surveys in the past? Did you complete the 1997 survey? Did you complete the 1996 survey (before Campbell arrived)? Nearly all respondents recalled whether they had participated, but some could not remember which year or years. In 2000, respondents were asked only: Did you complete one of our surveys in the past? The 1998 and 2000 measure of repeat respondents was those who answered yes to this question. This measure does not claim to be as accurate as a panel design; it does, however, allow for comparisons from nearly the same sample of respondents at different points in time.

71. The means for repeat respondents by construct: Organizational development, $1997=3.70,1998=3.96,2000=2.74$; Newsroom Structure, $1997=3.83$, 1998=3.84, 2000=2.90; Public Journalism, 1997=3.65, $1998=3.75,2000=3.24$.

72. Neuzil, Hansen, and Ward, "Twin Cities Journalists' Assessment of Topic Teams," 14.

73. Charles Rappleye, "Cracking the Church-State Wall," Columbia Journalism Review, January/February 1998, 20-23; William Woo, "Why Willes is Wrong," Columbia Journalism Review, January/February 1998, 27; Underwood, When MBAs Rule the Newsroom; Hickey, "Money Lust," 28-36; Gade, "Managing Change," 148-52.

74. Sylvie and Witherspoon, Time, Change and the American Newspaper, 41-42, 59-63; Alicia Shepard, "Consultants in the Newsroom," American 
Journalism Review, September 1996, 19-23.

75. See, for example, Anthony DiBella and Edwin Nevis, How Organizations Learn (San Francisco:Jossey-Bass, 1998); Argyris, Knowledge for Action; Labianca, Gray, and Brass, "A Grounded Model of Organizational Schema Change During Empowerment;" Gentry, "Analysis of Change at a Small Daily Newspaper."

76. Steven H. Chaffee and Miriam J. Metzger, "The End of Mass Communication," Mass Communication and Society 4 (fall 2001): 365-79. 